\title{
Laatuajattelulla uuteen oppimisympäristöön
}

\author{
Laatu koulutuksessa on ollut vilkkaan keskustelun \\ aiheena viimeksi kuluneen vuoden aikana. \\ Samalla kun monet oppilaitokset ovat innokkaasti jo \\ rakentelemassa omaa laatujärjestelmäänsä, jotkut \\ pohtivat laatuajattelun oikeutta koulutuksessa.
}

On viitattu mm. mahdolliseen epäterveeseen kilpailuun ja epäsosiaaliseen tilanteeseen, jossa heikot oppilaat jäisivät vahvojen varjoon. Laatuajattelu on tällöin ymmärretty kilpailuksi sellaisella laadulla, josta koulutuksessa ei voi olla kysymys. Yritysmaailman laatuajattelua ei voi sellaisenaan soveltaa koulutukseen, siksi on paikallaan pohtia koulutuksen laadun olemusta.

Koulutuksen laadun parantaminen on osa sitä prosessia, mitä koko julkisella sektorilla käydään. Monet ovat sitä mieltä, että nimenomaan julkisella sektorilla laatutyössä on tehtävää. julkisten laitosten menetelmät ovat monesti jo luonteensakin puolesta itseään toistavia, standardoituja ja alttiita virheille eivätkä ota huomioon asiakasta. Ne tarjoavat otollisen maaperän laatujohtamisen filosofialle ja menetelmille (Smith 1994). Vaikka julkisen sektorin budjetteja ollaan supistamassa, palvelun parantamiseen kohdistuu entistä suurempia odotuksia. Kysymys on myös kilpailusta yksityisen sektorin kanssa. Yksityistäminen ja tiettyjen kunnallisten tai valtion palvelusten siirtäminen avoimeen kilpailuun vaatii julkisia organisaatioita tehostamaan toimintaansa. Vielä Suomessa ei ole talolla kovin paljon yksityisiä koulutuspalveluja, mutta sekin aika saattaa tulla pian. Koulutustoimiala ei voi jäädä katsomaan sivusta, miten koulutuspalveluja jatkossa kehitetään. Tätä tilannetta Smith (emt) kuvaa julkisen laitoksen "hengissä pysymiseksi" ja uskottavuudeksi. Uskottavuus riippuu siitä, miten tärkeäksi veronmaksaja kokee laitoksen tehtävän ja millaisena hän pitää sen tarjoamien palvelujen laatua.

Laatuajattelu koulutuksessa ei missään nimessä ole myöskään muoti-ilmiö, kuten Hämäläinen ja Kauppi (1993) näkevät. Puhdasveriset humanistit leimaavat laatuajattelun kovin helposti tekniseksi, insinööreille kuuluvaksi asiaksi ja tällä verukkeella eivät katsoisi sen kuuluvan sellaiselle alalle kuin koulutus. Tämä käsitys perustuu ensinnäkin vanhanaikaiseen käsitykseen laadusta ja toiseksi väärään oletukseen laatuajattelun soveltumisesta julkiselle sektorille. Kuten edellä todettiin, laatuajattelulla on mitä parhaat sovellusedellytykset julkisissa palveluissa. Näin erityisesti silloin, kun laatuajattelu ymmärretään muuksi kuin standardien noudattamiseksi. Laatustandardit on ymmärrettävä laatuajattelua koskevien paradigmojen uusiksi elementeiksi. Niistä otetaan ja sovelletaan aineksia tapauskohtaisesti. Varsinainen laatuajattelu perustuu asioiden ymmärtämiseen ja välittämiseen, jota Pirsig (1986) oivallisesti kuvaa. Hänen mukaansa välittäminen syntyy oman työn arvostamisen kautta. Ihminen, joka arvostaa työtään ei voi tehdä työtään huonosti.

Laatuajattelu on siis jotakin muuta yritysmaailmassa kuin koulutuksessa, mutta sen perusfilosofiaa on mahdollista ja myös tarpeellista soveltaa koulutukseen. Nykyaikaisessa liikkeenjohdossa puhutaan prosessijohtamisesta. 
Sen perusperiaatteena on uudistaa yrityksen ydinprosesseja. Perinteinen tapa organisoida työtä on johtanut tehottomiin ja raskaisiin organisaatioihin. Prosessijohtamisessa on kysymys syvällisestä toiminnan uudistamisesta niin, että se vaikuttaa koko organisaation tasolla. Hannus (1993) kuvaa tätä tilannetta perinteisen jäävuorimallin tapaan seuraavasti:

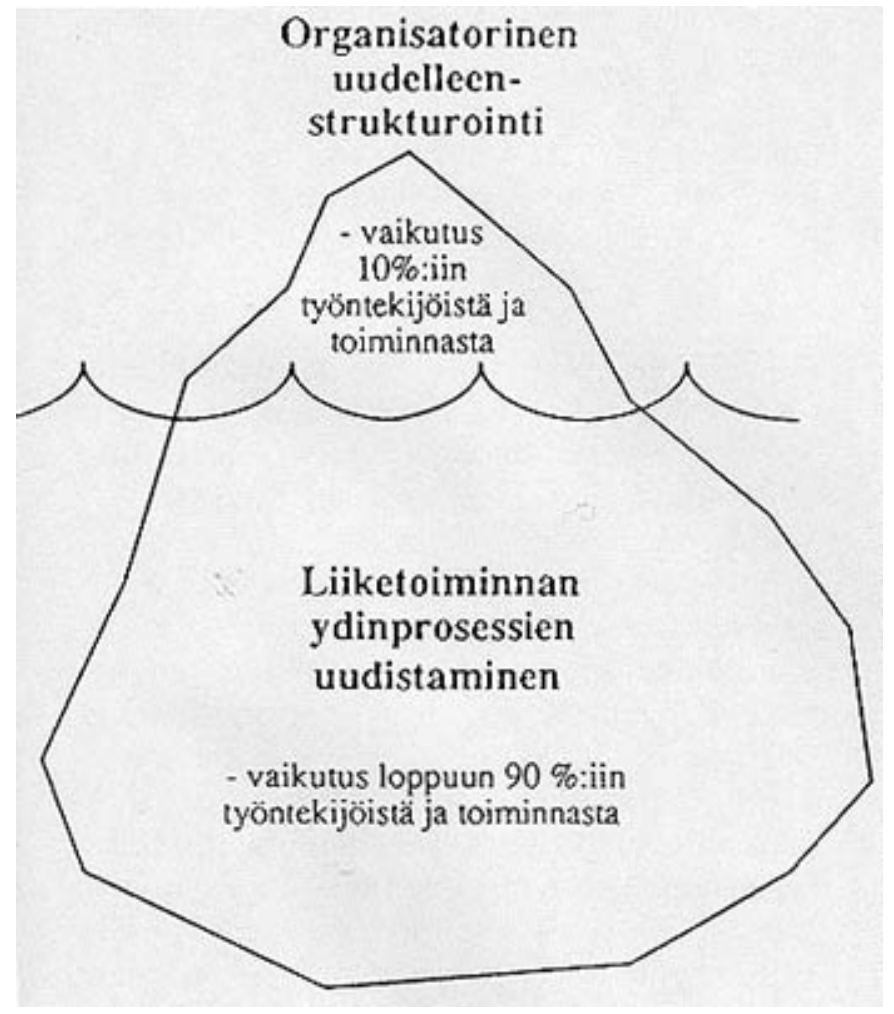

\section{Kuvio 1. Prosessijohtamisen vaikutukset Hannuk- sen (1993) mukaan}

Laatutoiminta on osa prosessijohtamista. Siinä paneudutaan organisaation toimintaprosesseihin ja pyritään niiden kehittämiseen.

Sovellettaessa laatuajattelua oppilaitoksiin ensimmäinen ongelma on asiakkaan määrittely. joidenkin mielestä asiakas on se, joka maksaa. Tällä perusteella he nimeävät oppilaitoksen asiakkaaksi kunnan tai valtion. Useimmat kuitenkin lähtevät siitä, että oppilas on ensisijaisesti koulun asiakas. Toisinaan oppilaan ääntä käyttää hänen huoltajansa. Asiakaskysymys on todella syvällisesti pohdittava asia. Ståhle (1993) näkee sen osana koko oppilaitosfilosofiaa, tietokäsitystä ja ihmiskuvaa.

\section{UUDEN OPPIMISYMPÄRISTÖN VAATIMUKSET JA MAHDOLLISUUDET}

Asiakaslähtöisen oppimisympäristön kehittäminen liittyy sekä oppilaitoksen sisäiseen työskentelyyn että sen ulkoisiin yhteyksiin. Oppimisympäristöllä voidaan vaikuttaa asiakkaan (oppijan) kokemaan laatuun ja mahdollisuuteen toimia omista lähtökohdistaan käsin ja itseohjautuen. Uudistuva tiedon- ja oppimisen käsitys liittyy voimakkaasti oppimisen laatuun ja vaikuttaa opetuksen muotoihin. Viime aikoina on puhuttu luokkahuonetyöskentelyn sijasta oppimisverstaista tai työpajoista. Uudistuva oppimiskäsitys pohjautuu konstruktivismin nimellä tunnettuun suuntaukseen, jossa korostuu havaitsijan aktiivinen osuus havaintoprosessissa. Pohjana on Neisserin (1982) havaintoteoria, jonka mukaan havaitsija poimii informaatiota. Oppija siis konstruoi jatkuvasti uudelleen havaintojen kohteen perusteella uusia skeemoja reflektoiden ja rekonstruoiden käsitesisältöjään henkilökohtaiseksi tietämykseksi.

Uudet oppimiskäsitykset ovat pohjana luotaessa avointa asiakaslähtöistä oppimisympäristöä. Sen tunnuspiirteitä ovat mm. seuraavat seikat:

* Oppiminen tapahtuu oppimisverstaassa (kognitiivisessa työpajassa), joka on vastakohta "opetustehtaalle" oppiminen tapahtuu siinä kontekstissa (toimintaympäristössä), joka osoittaa, miten tietämystä ja taitoja sovelletaan jokapäiväisessä elämässä - oppiminen on kokonaisvaltaista ja kokemuksellista

* Uudet tiedot ja taidot hankitaan aktiivisesti ongelmanratkaisu- ja toimintatehtävien avulla (oppimistehtävät) - oppiminen on prosessi, jonka tuloksia ei tarkastella yksinomaan lopputuloksesta käsin

* Oppiminen on assosiatiivista yhdistelyä eli uutta tietoa yhdistetään aiemmin opittuun luovan ajattelun ja kriittisen pohdiskelun avulla 
* Opiskelu on sekä yksilöllistä että ryhmätoimintaa - yhteistyötaidot ovat oleellinen osa oppimistavoitteita

* Opiskelussa käytetään hyväksi kaikkia mahdollisia tietolähteitä ja välineitä (mm. tietokannat, sähköposti, teleopetus)

* Opiskelu on itseohjautuvaa, jossa opettajan roolina on toimia ohjaajana ja tukijana -oppimisen kontrolli on oppijalla

Edellä kuvattua oppimiskäsitystä sanotaan uudistavaksi oppimiseksi. Uudet tiedon ja oppimisen käsitykset korostavat opiskelijaa aktiivisena oppijana, joka voi oppia monella eri tavalla. Opiskelu ei ole paikkaan eikä aikaan sidottua, se voi tapahtua esim. työn ohessa. Näin erityisesti aikuiskoulutuksessa, mutta entistä enemmän myös nuorisoasteen koulutuksessa. Tämän on johtanut monimuoto-opetuksen laajamittaiseen soveltamiseen.

Syynä koulutusteknologian kehittymiseen on nähtävissä kaksi tärkeää perustekijää. Toinen on tieto- ja teletekniikan nopea kehittyminen, mikä mahdollistaa nopeat ja vaivattomat televiestintäyhteydet koko maassa. Tekniikan ohella televiestinnän palvelumaksut ovat laskeneet huimaa vauhtia niin, että siihen perustuvat koulutuspalvelut ovat myös kustannuksiltaan kilpailukykyiset. Toinen tärkeä perustekijä on pedagoginen. Perinteiset pelkästään lähiopetukseen perustuvat opetusmenetelmät ovat osoittautuneet riittämättömiksi. Nyt kaivataan enemmän yksilöllisyyttä, yhteistyötä, joustavuutta, itseohjautuvuutta, ja tehokkuutta. Tämä puolestaan edellyttää ajasta ja paikasta riippumattomuutta, mikä on vaihtoehto "pulpetissa istumiselle".

Perinteisesti oppikirja on ollut hyvin keskeisessä asemassa opetuksen toteutuksessa. Nyt sen asema on vakavasti uhattuna. Oppikirjan käsitettä täytyy laajentaa koskemaan myös sähköisessä muodossa olevia materiaaleja. Multimedia- ja hypermediamateriaalit ovat nyt astuneet

sellaisia kehitysaskelia, että niiden laajamittainen hyväksikäyttö on voinut alkaa. Kysymyksessä ei ole vain teknologinen kehitys, vaan ennen muuta oppimis- ja tiedonkäsityksessä tapahtuneet muutokset. On puhuttava uudesta tavasta hahmottaa asioita. Oleellista tässä on se, että oppimisprosessi etenee oppijan omien assosiaatioiden kautta. Kirjan tai muun perinteisen oppimateriaalin eteneminen tapahtuu tekijän tai opettajan tietorakenteen mukaisesti.

Opetusoppimistapahtuman laadullista kehittämistä silmälläpitäen Hämeenlinnan Ammatillisessa opettajakorkeakoulussa on käynnistetty PEDATEL- ja HYPERMEDIA-projektit.

PEDATEL-projekti, jonka toisena osapuolena on Telekehityskeskus, koskee Ammatillisessa opettajakorkeakoulussa ja eräissä sen harjoittelukouluissa pedagogisen televiestinnän kokeilua, tutkimusta ja kehittämistä monimuoto-opetuksen piirissä. Projektin tavoitteena on kehittää televiestinnän teknisiä sovelluksia monimuoto-opetuksen pedagogiseen kehittämiseen päämääränä tuottaa ammatilliselle opettajankoulutukselle teknisesti ja toiminnallisesti ihanteellinen viestintäjärjestelmä, jota voidaan operatiivisen soveltamisen lisäksi käyttää mallina ja opetusvälineistönä myös muualla. Projektin piirissä suoritettava kehittävä kokeilu perustuu osallistuvien opettajien jatkuvaan yhteissuunnitteluun, jota pyritään toteuttamaan aika- ja paikkariippumattomuuden periaatteella. Toisin sanoen projektin kuluessa varmistetaan tekniset edellytykset reaaliaikaiselle ohjauskeskustelulle. Projektissa on jatkuvan koulutuksen periaatteella ylläpidetty ja lisätty teleteknisten palvelujen käytettävyyttä. Yksilöllisen opiskeluotteen varmistumiseksi on oppimisen ohjaamista kehitetty noudattamalla oppimislaboratorion ominaispiirteiden asettamia vaatimuksia ja kannustettu oppijoita itseohjautuvuuteen. Yksilöllistä ajasta ja paikasta riippumatonta ohjausta on tehostettu kehittämällä televiestintäpohjaista oppimispäiväkirjajärjestelmää. Tähän mennessä projekti on tuottanut monia arvokkaita opettamisen ja oppimisen infrastruktuurin kehittämisideoita, jotka luovat entistä 
parempia edellytyksiä yksilöllisen ja monimuotoisen opetuksen toteuttamiselle sekä sen suunnittelemiselle ja edelleen kehittämiselle.

HYPERMEDIA-projektin avulla pyritään selvittämään oppijoiden tiedon omaksumisprosessin luonnetta ja etenemistä. Opetuskokeilujen ja tutkimuksen avulla seurataan ja analysoidaan oppijoiden assosiaatioketjuja ja päättelyn logiikkaa. Tässä projektissa kehitetään hypermediaohjelmaa, jossa hypertekstin tekstikatkelmien ja niihin liitettävien kuva- ja äänielementtien avulla voidaan virittää informaatiopalojen assosiatiivista linkittämistä ja yksilöllisten ajatuspolkujen reitittämistä tukevaa tiedon prosessointiavaruutta. Ohjelmaa kehitetään sellaiseksi, että se toisaalta optimaalisesti tukee yksilöllistä oppimista, mutta toisaalta antaa opetuksellisia viitteitä tarkoituksenmukaisten oppimateriaalien ja oppimisympäristöjen rakentamiseen.

Uudistuvaan oppimiskäsitykseen liittyy ongelmia, jotka esim. hypermediaoppimisympäristöä kehitettäessä tulee muistaa. Goodrum ym. (1993) ovat rikastetun oppimisen (Enriched Learning) ympäristöä pohtiessaan todenneet konstruktivistiseen oppimiseen perustuvan opetuksen aiheuttavan oppijoille mm. seuraa via vaikeuksia: 1) konstruktivistisen oppimisen synnyttämä korkea kongnitiivinen kuormitus, 2) vastuu omasta oppimisesta ja sen suunnittelusta ja 3) välttämättömyys omaksua entisestä poikkeava oppimisprosessi. Tämä merkitsee itseasiassa sitä, että "vanhaan opiskelutekniikkaan" oppineet opiskelijat tulee ensin perehdyttää uuteen tapaan opiskella. (ks. myös Suonperä 1993)

Kognitiivista työpajatyöskentelyä (Cognitive apprenticeship approach) on sovellettu jo tietokoneavusteiseen oppimiseen (ks. de Bruijn 1992). Tämän työskentelytavan taustalla on tilanneoppimisen menetelmä, joka tarkoittaa tietämyksen ja taitojen hankkimista siinä kontekstissa, joka osoittaa, miten niitä käytetään jokapäiväisessä elämässä. Näin tarvittava tietämys tulee määritellyksi ja perustelluksi tilanteessa, jossa sitä konkreettisesti sovelletaan. Käsitteellinen ja kokemusperäinen tieto hankitaan aktiivisesti ongelmanratkaisuja toimintatehtävien avulla (Collins ym. 1989). Kognitiivisessa työpajassa pyritään siis sellaiseen käytännölliseen sovellukseen uusiutuvasta oppimiskäsityksestä, jonka avulla on mahdollista opiskella itseohjautuvasti, aktiivisesti työskennellen ja sellaisessa oppimisympäristössä, joka osoittaa opittavan asian mielekkyyden ja yhteyden käytännön tarpeisiin.

\section{KOLBIN NELJÄ OPPIMISEN TAPAA}

Eri ihmiset oppivat eri tavoin. viimeisen vuosikymmenen kuluessa on puhuttu paljon erilaisista oppimistyyleistä ja muista oppimisen muodoista. Siitä ollaan paljolti yksimielisiä, että oppiminen on yksilöllistä ja että siitä johtuen on olemassa erilaisia oppimistyylejä. Kolb (1984) on erottanut neljä erilaista oppimisen perustapaa, jotka ovat: luova, assosioiva, sääntöinen ja sopeutuva oppiminen. Luova oppiminen tarkoittaa nimensä mukaisesti intuitiivistä, avointa ja tunnepitoista oppimista, jossa ei välttämättä pyritä ilmiön käsitteellisyyden ymmärtämiseen. Assosioiva oppiminen on luonteeltaan po diskelevaa ja aktiivista toimintaa, jonka pohjana ovat omat kokemukset ja niiden liittäminen uusiin asioihin. Sääntöinen oppiminen on kurinalaista ja systemaattista ajattelua, ilmiön ymmärtämiseen tähtäävää ja teoriaan tukeutuvaa. Sopeutuva oppiminen tähtää käytännön ratkaisujen löytämiseen ja sovellusten luomiseen. Nämä Kolb on integroinut ja puhuu kokonaisvaltaisesta oppimisesta, jonka eri oppimistyylien mukainen painotus riippuu olosuhteista ja oppimisen tavoitteista.

Kolbin kokonaisvaltaisella oppimisteorialla on samankaltaisuutta toiminnan teorian kanssa, jossa suhtaudutaan kriittisesti pinnalliseen ja sirpalemaiseen tietoon sekä sen oppimiseen (Engeström 1987). Oleellista siinä on ristiriitojen olemassaolo. Oppijalla on ristiriita aiemmin oppimansa ja uuden tiedon välillä. Perinteinen työssä oppimisen malli perustuu käytännön logiikalle, kun taas toiminnanteorian pohjalle rakentuva oppiminen tähtää teoreettisen ajattelun kehittymiseen. Tämä jo Deweyn kehittelemä "tekemällä oppimisen" malli perustuu siihen, että ihminen tutkii ympäristöä, havainnoi ja kokeilee sekä konstruoi tältä pohjalta oppimaansa. 
Mielenkiintoista uudessa oppimisympäristössä on se, että oppimisverstas laajenee uuden informaatioteknologian kautta myös fyysisen "pajan" ulkopuolelle tietoverkkojen välityksellä. Tällöin puhutaan "virtuaalitodellisuudesta". Itse asiassa voitaisiin puhua myös "virtuaalipajasta", joka käyttää paikallisen tietokannan hyväksi myös ulkoisia tiedostoja.

\section{KOULUN LAATUJÄRJESTELMÄ}

Kokonaisvaltainen laadunhallinta (TQM) perustuu siihen, että oppilaitos pystyy luomaan systeemin, jossa laadun jatkuva kehittäminen on mahdollista. Kysymys ei siis enää ole siitä, että luotettaisiin yksittäisen opettajan ammattitaitoon ja sen ylläpitoon. Laadunhallinta koskee koko oppilaitosta. Toiminnan perustaksi luodaan systeemi, jossa voidaan yhdessä sopia laatutavoitteista ja niiden toteuttamisesta. Se edellyttää kaikkien osallistumista ja sitä kautta jatkuvaan arviointiin ja uusiutumiseen. Kun laatua kehitetään, se tarkoittaa koko systeemin parantamista, huomion kiinnittämistä siihen vuorovaikutus- ja yhteistyöprosessiin, jonka tuloksena tuote tai palvelu syntyy. (Ståhle 1993)

Samalla kun oppilaitoksen laatujärjestelmää pohditaan, tulee kehittämistyön alle koko toiminta ja sen organisointi. Kun tavoitteena on opetuksen jatkuva kehittäminen, oppilaitoksesta Ståhlen mukaan kehittyy samalla systeemi, joka on avoin, orgaaninen, moniarvoinen ja monimutkainen. Banathy (1991) on visioinut oppilaitoksen, joka

* tekee yhteistyötä ympäristönsä monien systeemien kanssa

* kykenee muuntautumaan joustavasti ympäristön haasteiden mukaisesti

* löytää uusia tavoitteita ja toimintasarkoja ympäristössään tekee työtä jatkuvasti muuttuvissa olosuhteissa, jatkuvassa epävarmuudessa ja epäselvyydessä

* toimii luovasti monimutkaisissa ja epäselvissä tilanteissa, jotka ovat sen normaalia arkipäivää

* on oppimiskykyinen organisaatio: kykenee arvioimaan ja kehittämään omaa oppimistapaansa, prosesssoimaan nopeasti yhä enemmän informaatiota, jakamaan tietoa laajasti sekä muuntamaan informaation organisaation yhteiseksi tiedoksi

* kehittää jatkuvasti uusia itsearvioinnin tapoja

* ymmärtää että jatkuva tiedollinen uudistuminen vaatii kaksisuuntaista kehitystä systeemissä, erikoistumista ja integrointia.

Banathy näkee, että nykyaikainen oppilaitos tarvitsee runsaasti yhteyksiä itsensä ulkopuolelle taatakseen tämän verkoston kautta laadun jatkuvan kehittämisen. Ståhlen mukaan pelkän ylläpitämisen aika on ohi. Toimiva, energinen systeemi tuottaa laadukasta tulosta vain, jos toiminnalla on selkeä suunta ja tarkoitus.

Ståhle (emt) kiteyttää kaksi pääperiaatetta, joiden varassa opetuksen laadun kehittäminen joko onnistuu tai epäonnistuu:

1. Opetuksen laatu syntyy koko systeemin jatkuvasta kehittämisestä.

2. Laadun kehittäminen ja kehittämisen suunta määräytyvät aina asiakkaan tarpeesta.

Oppilaitoksen olennainen laatutyö alkaa silloin, kun keskustelu laadusta, sen tuottamisen periaatteista ja arvioinnista oppilaitoksessa alkaa. Vuorovaikutuksen peruspilareita ja siten TQM:n työvälineitä ovat:

* kyky käyttää laajapohjaisesti keskustelua kehittämisen ja päätöksenteon välineenä

* tiimityön organisointi

* systeemin sisällä toimiva palaute- ja arviointijärjestelmä

* Ståhle pitää tiimityötä välttämättömänä riittävän laajan keskustelupohjan synnyttämiselle, samoin kuin selkeille toimenpiteille. Tiimit, joilla on vastuuta ja riittävästi toimeenpanovaltaa, ovat kehittämisen perusyksikkö. Näin siis laatutoiminnan kehittämisen perustana on koko kouluorganisaation kehittäminen siihen suuntaan, mihin työelämä on vastaavasti edennyt. 
* Viimeaikaiset kehityskuvaukset yhteiskunnassa ja työelämässä ja niiden perustalle kehitetty tiimiorganisaatio ovat loppujen lopuksi vain osa koko koulun kulttuurin muutosta. Tiimiorgnisaatio on väline uuteen kouluun, jossa vallitsee uusi arvomaailma ja uudet toimintatavat. Tässäkin suhteessa voidaan katsoa työelämän organisaatioihin ja niiden kulttuurin kehitykseen. Juuti on kuvannut yrityskulttuuria ja sen taustalla olevia tekijöitä seuraavasti (kuvio 2):

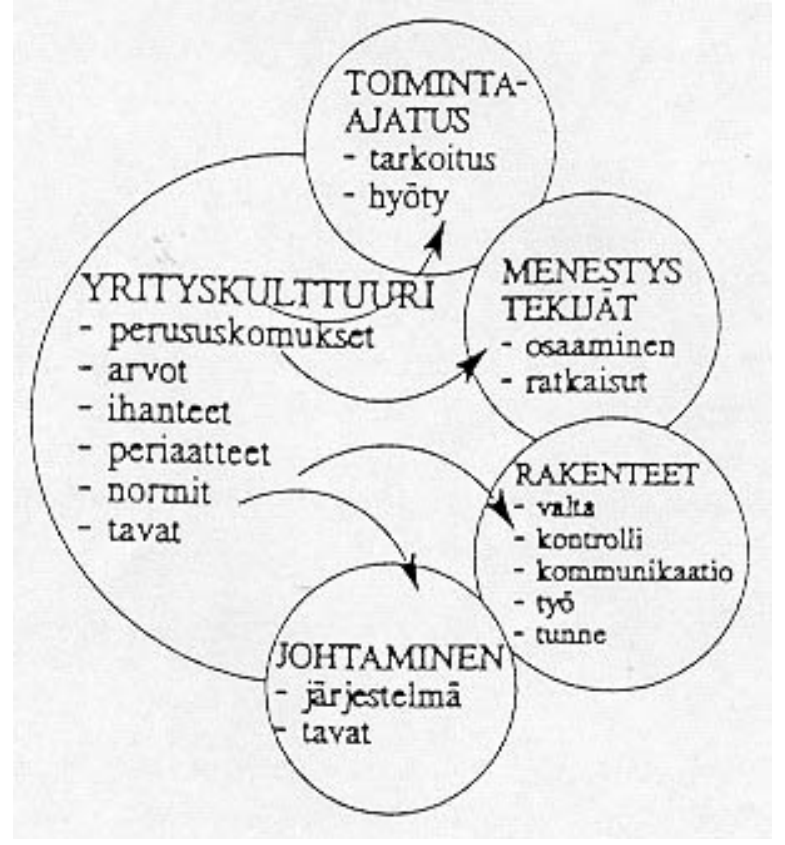

Kuvio 2. Yrityskulttuuri (Juuti, 1992)
Kun viime aikoina on puhuttu yritysorganisaatioiden kehittämisestä ja muutoksesta uuteen toimintakulttuuriin, on tullut esille kokonaan uuden paradigman kehittämisen tarve. Paradigmalla tarkoitetaan tässä todellisuuskäsitystä, jonka avulla havainnointi, arvottaminen ja toiminta suoritetaan. Se on siis ikäänkuin yhteinen maailmankatsomus, joka luo ja ylläpitää organisaation toimintatapaa, käyttäytymistä, strategioita ja kulttuuria (Juuti, 1992). Nyt ollaan siirtymässä verkosto-organisaation järjestelmään, joka perustuu matriiseille ja tiimeille. Vanhat toimintamallit ja niiden taustalla olevat byrokraattiset ja hierarkiset järjestelmät ovat kriisissä. Muutos on mahdollista vasta, kun usko uuden järjestelmän paremmuuteen voittaa vanhan järjestelmän. Joustavat organisaatiomallit saattavat aluksi tuntua turvattomilta, kun niitä vertaillaan vanhaan byrokraattiseen malliin, joka sisältää monia ulkoisesti palkitsevia aineksia. Yksilöllinen menestyminen ei kannusta ryhmätyöhön, jos siinä ei nähdä myös oman menestymisen mahdollisuuksia. Uudentyyppistä paradigmaa on sovellettu jo lukuisissa yrityksissä.

Oppilaitokset ovat tänä päivänä saaneet entistä enemmän itsenäisyyttä ja päätösvaltaa koulutasolla esiintyviin asioihin. Oppilaitokset voidaan oikeastaan ymmärtää yrityksiksi. Vaikka asiasta vallitsee vähintäänkin kahdenalaista käsitystä, oppilaitokseen voidaan soveltaa yritysmaailman hyviksi kokemia kehittämistoimia. Olemme esimerkiksi Ammatillisessa opettajakorkeakoulussa Hämeenlinnassa kehittäneet toimintaamme tiimiorganisaatioksi (ks. tiimiorganisaatiosta ja laatutyöstä Helakorpi 1994). Opettajat alansa asiantuntijoina muodostavat tiimejä, joilla on suuri liikkumavara koulutuksen toteutuksessa ja käytännön opetuksessa. Tämä pari vuotta jatkunut kokeilu on kyselyjen ja oman tuntuman kautta osoittautunut menestykseksi. Luultavasti kukaan ei halua paluuta entiseen. Työn mielekkyys on kohonnut, opiskelijatyytyväisyys on selvästi noussut ja mukautuminen muutoksiin on helpottunut. Erityisesti joustavuus ja innovatiivisuus on lisääntynyt. Nopeatkin muutokset on voitu toteuttaa hallitusti. Taloon on tullut uutta ilmettä - olemme uuden opettajankoulutuskulttuurin tiellä. Laatuajattelun toteutuksessa on myös nojauduttu tiimien toimintaan ja kehittämisideoihin. Oikeastaan on vaikeaa ajatella, miten muuten laatuajattelu voitaisiin käytännössä toteuttaa. Tavanomaista on, että oppilaitoksen kehittämiskysymyksiä käsitellään esimerkiksi opettajien kokouksissa. Se on ehdottomasti liian suuri kokoonpano pohdiskeluun, joka tarjoaisi kaikille jäsenille aktiivisen osallistumisen mahdollisuuden.

Aikojen kuluessa oppilaitokseen muodostuu tiettyjä tapoja ja normeja. Näistä muodostuu koulun kulttuuri, joka vaikuttaa mm. sen ilmapiiriin. Parhaassa tapauksessa koulun kulttuuri on sen työtä ja jäseniä tukeva ja turvallisuutta antava. Vahvalla kulttuurilla on myös kielteinen puolensa. Se voi estää luovuuden sekä toimia muutoksen ja kehityksen jarruna. (ks. Hämäläinen - Sava, 1989).

Nyt koululta odotetaan rohkeaa uudistumista. Vanha toimintakulttuuri on "poisopittava" ja siirryttävä uuden paradigman mukaiseen toimintatapaan. Oppimisympäristöä on tutkailtava sen kaikilta puolilta. Uudistaminen koskee sisäisen työn kehittämistä toiminnalliseen ja itseohjautuvuuden periaatteille nojaavaan suuntaan, ja samalla se merkitsee uudistumista ulkoisissa suhteissa: enemmän yhteyttä toisiin oppilaitoksiin 
ja työelämään sekä tietoverkkojen avulla aina ulkomaisiin tieto- ja yhteistyökohteisiin. - Koulu on mielenkiintoisen askeleen edessä, uskallammeko ottaa sen?

\section{LÄHTEET}

Banathy, B. H. 1991. Systems Design of Education: A journey to Create the Future. Englewood Cliffs, Educational Tecbnology Publications. N. J.

de Bruijn, H. F. M. 1992. Kognitiivinen työpajatyöskentely. Sovellutuksena tietokoneavusteinen oppiminen. Aikuiskasvatus 4/1992.

Collins, A. - Brown, J. S. - Newman, S. E. 1989. Cognitive Apprenticeship: teaching the Craft of Reading, Writing and Mathematics. In Resnick, L. B. (eds). Knowing, Learning and Instruction: Essayas in Honour of Robert Glaser, 449-453. Hillsdale. N. J.: lawrence ErIbaum Associates.

Engeström, Y. 1987. Learning by Expanding. Orienta-Konsultantit. Helsinki.

Goodrum, D. A. - Dorsey, L.. T. - Schwen, T. M. 1993. Definiting and Building an Enriched Learning and Information Environment. Educational Technology. November/1993.

Hannus, J. 1993. Prosessijohtaminen. Ydinprosessien uudistaminen ja yrityksen suorituskyky.

HM\&V Research Oy. Gummerus Kirjapaino Oy Jyväskylä.

Helakorpi, S. 1994. Oppilaitoksen tuloksellisuus ja laadunhallinta. Ammatillinen opettajakorkeakoulu. julkaisuja 100. Hämeenlinna.

Hämäläinen, K. - Kauppi, A.. 1993. Mitä on koulutuksen laatu? Aikuiskasvatus 4/93.

Hämäläinen, K. - Sava, L. 1989. Koulun ihmissuhteet. Suomen Kaupunkiliitto. Jyväskylä.

Juuti, P. 1992. Yrityskulttuurin murros. Aavaranta-sarja n:o 31. Aavaranta Oy Tampere.

Kolb, D. A. 1984. Experiential learning. Experience as the source of learning and development. Englewood cliffs. Prentice Hall. Inc. New Jersey.

Neisser, U. 1982. Kognitio ja todellisuus. Weilin+Göös. Espoo.

Paananen, V. S. (1992) Työpajan oppimistoiminta. julkaisematon kasvatustieteen pro gradu.. Kasvatustieteen laitos. Jyväskylän yliopisto.

Pirsig, R.. M. 1986 Zen ja moottoripyörän kunnossapito. WSOY Helsinki.

Smith, A. K. 1994. Laatujohtaminen julkisella sektorilla. Yritystalous-lehti 1/94.

Ståhle, P. 1993. TQM - lisää laatua opetukseen. Artikkeli Aikuiskasvatus 4/93.

Suonperä, M. 1993. opettamiskäsitys,, oppijakeskeisen opettamiskäsityksen perusaineksia. Educons Oy. Hämeenlinna. 